\title{
Variation in vasotocin immunoreactivity in the brain of recently isolated populations of a death valley pupfish, Cyprinodon nevadensis
}

\author{
Sean C. Lema and Gabrielle A. Nevitt
}

\begin{abstract}
Pupfishes in the Death Valley region of California and Nevada comprise a monophyletic group of populations that became isolated in remote streams and springs over the past 20,000 years. These aquatic habitats show considerable ecological diversity, and allopatric populations have evolved differences in morphology and behavior. Here we investigated whether the divergence of pupfish populations in Death Valley might be associated with changes in arginine vasotocin (AVT). We used immunocytochemistry to compare the expression of AVT in the brain of Amargosa pupfish (Cyprinodon nevadensis) from two Death Valley populations: (1) the Amargosa River - a highly variable desert stream containing the Cyprinodon nevadensis amargosae subspecies, and (2) Big Spring - a comparatively stable springhead and outflow inhabited by Cyprinodon nevadensis mionectes. These particular populations have been isolated from each other for only 400-4000 years. In both populations AVT-immunoreactive somata localized to parvocellular and magnocellular neurons in the preoptic area, with AVT-immunoreactive fibers extending ventrolaterally to innervate the pituitary. We found that both parvocellular and magnocellular AVT-immunoreactive neurons were significantly larger in males and females from the Amargosa River population than in same sex pupfish from Big Spring. Our findings suggest that the divergent ecological conditions of these two habitats have brought about changes in AVT pathways in the brain.
\end{abstract}

Keywords: Arginine vasotocin; AVT; Hormone evolution; Pupfish; Hormonal mechanisms; Vasopressin; AVP

\section{Introduction}

Pupfishes (Genus Cyprinodon) in the Death Valley region of California and Nevada provide one of the clearest displays of allopatric evolution in North America. Death Valley pupfishes evolved into a clade of seven extant taxa living in remnant aquatic habitats that became isolated by the increasingly arid climate over the past 20,000 years (Miller, 1981). Even though these habitats occur within a restricted geographical area, they are extremely diverse (Soltz and Naiman, 1978). Some Death Valley pupfishes occupy groundwater-fed oases with a stable temperature and habitat size. Other populations live in desert streams that fluctuate widely in temperature and experience alternating desiccation and flooding over the course of a year. And one pupfish is isolated to a small pool that lies $15 \mathrm{~m}$ below the ground and leads to a water-filled cavern of unknown depth. Because of this ecological variety, the allopatric populations have diverged in morphology (Miller, 1948) and social behavior (for review, see Soltz and Hirshfield, 1981), yet show little genetic change (Duvernell and Turner, 1998).

The recent isolation of pupfish populations in Death Valley provides the opportunity to study the role that changes in hormone physiology play in the initial stages of evolutionary divergence. Examining how hormones and other components of hormone physiology 
(i.e., receptors, conversion enzymes, binding proteins) respond to ecologically dissimilar conditions can lead to an understanding of the endocrine regulation of phenotypic traits, as well as how these traits were modified when populations became isolated in their respective habitats (e.g., Ketterson and Nolan, 1999; West-Eberhard, 1992). Which specific hormonal pathways contribute to the phenotypic differences among Death Valley pupfishes, however, has not been addressed.

The peptide hormone arginine vasotocin (AVT) is a prime candidate for physiologically mediating the diversification of Death Valley pupfishes. AVT previously has been recognized in fish to regulate plasma osmolality (Kulczykowska, 1997), vasodilation (Warne and Balment, 1997), and the secretion of adenohypophyseal hormones (Baker et al., 1996). But AVT also acts within the central nervous system to modulate neuronal activity (Rose et al., 1995) and regulate behavior (Salek et al., 2002; for review, see Goodson and Bass, 2001).

Recent evidence has implicated AVT and its mammalian homologue, arginine vasopressin (AVP), in the evolution of social behaviors in a variety of taxa (for review, see Insel and Young, 2000). Variation in brain AVP immunoreactivity has been found to be associated with differences in aggression between species of Peromyscus mice (Bester-Meredith et al., 1999). Similarly, Cushing et al. (2001) recently showed that the effects of exogenous AVP on mate affiliation behaviors differ between populations of prairie voles (Microtus ochrogaster), and suggested that this variation was associated with different selective pressures in their habitats. Yet how ecological variation among habitats shapes AVP/ AVT physiology to contribute to population differences in behavior is not clear.

The present study examines the expression of AVT immunoreactivity in the brains of Amargosa pupfish (Cyprinodon nevadensis) from two allopatric populations: (1) the Amargosa River occupied by the Cyprinodon nevadensis amargosae subspecies, and (2) the Big Spring population of Cyprinodon nevadensis mionectes. These two habitats span the range of environmental variation seen among Death Valley habitats (Table 1; Soltz and Naiman, 1978). The Amargosa River and Big Spring populations differ in temperature tolerance (Hirshfield et al., 1980) and social behavior (Soltz,
1974), even though they remain genetically similar (Duvernell and Turner, 1998). Paleohydrologic evidence from the Death Valley region indicates a period of increased precipitation and lake formation only 30004000 years ago (Enzel and Wells, 1997), and these particular populations are thought to have been isolated for less than that time (e.g., Soltz and Hirshfield, 1981). Here we compared the distribution, number, and size of AVT immunoreactive (AVT-ir) neurons in the brain of these two populations. Some of these results have been reported in preliminary form (Lema and Nevitt, 2003).

\section{Methods}

\subsection{Animal collection}

Pupfish were collected from the Amargosa River (amargosae subsp.) near Dumont Dunes, San Bernardino County, California, and from Big Spring (mionectes subsp.) in Nye County, Nevada. Pupfish were collected on April 6th and 7th, 2001 using minnow traps. Traps were set and recovered within $10 \mathrm{~min}$ to minimize confinement time and subsequent stress. All collections were made between 11:00 and 14:00 h. Mean $( \pm$ SE) water temperature recorded hourly over April 6th and 7 th in the Amargosa River was $12.92 \pm 0.73^{\circ} \mathrm{C}$ (range: $6.6-26.7^{\circ} \mathrm{C}$ ), and in Big spring was $27.05 \pm 0.08^{\circ} \mathrm{C}$ (range: 26.7-28.3 ${ }^{\circ} \mathrm{C}$ ). Salinity was $1.8 \mathrm{ppt}$ in the Amargosa River and 0.4 ppt in Big Spring. Pupfish collected from both the Amargosa River (males, $N=6$; females, $N=5$ ) and Big Spring (males, $N=5$; females, $N=5$ ) populations were matched for body size based on standard length $(\mathrm{mm})$ and body weight $(\mathrm{g})$ measurements. We specifically collected pupfish during the Spring since this is a time of year when both populations are breeding (e.g., Soltz, 1974).

Fish were immediately overanesthetized (MS222, tricaine methanesulfonate, Crescent Research Chemicals) and submerged in 4\% paraformaldehyde in phosphate buffered saline (PBS) for $24 \mathrm{~h}$ on ice with the brain exposed. Brains were cryoprotected first in $4 \%$ paraformaldehyde with 30\% sucrose in PBS and then 30\% sucrose in PBS, each for $24 \mathrm{~h}$ at $4{ }^{\circ} \mathrm{C}$. Brains were subsequently frozen on dry ice and stored at $-80^{\circ} \mathrm{C}$.

Table 1

Ecological descriptions of $C$. nevadensis populations sampled

\begin{tabular}{|c|c|c|c|c|c|c|}
\hline Habitat & Taxon & Description & $\begin{array}{l}\text { Temperature* } \\
\text { (yearly range) }\end{array}$ & Salinity* & Social organization & Population size \\
\hline Amargosa River & C.n. amargosae & Desert stream & Variable $\left(0-40^{\circ} \mathrm{C}\right)$ & $0.2-3.0 \mathrm{ppt}$ & $\begin{array}{l}\text { Loose aggregations } \\
\text { w/ high courtship }\end{array}$ & Extreme fluctuations \\
\hline Big Spring & C. $n$. mionectes & $\begin{array}{l}\text { Springhead and } \\
\text { outflow }\end{array}$ & Stable $\left(27.3^{\circ} \mathrm{C}\right)$ & $0.4 \mathrm{ppt}$ & Territorial breeding & $\begin{array}{l}\text { Minor seasonal } \\
\text { variation }\end{array}$ \\
\hline
\end{tabular}

\footnotetext{
*Values based on unpub. data from S. Lema.
} 


\subsection{Immunocytochemistry}

For AVT immunocytochemistry, brains of same-sex fish from different populations were paired by body size. Each pair was then processed together. Tissue was embedded in cryomatrix (Shandon, Pittsburgh, PA), frozen, and transversally sectioned $(30 \mu \mathrm{m})$ at $-17^{\circ} \mathrm{C}$ using a cryostat (Microm HM 505 N). Following drying on a warmer plate, slides were blotted with filter paper, immersed in phosphate buffer (PB) for $10 \mathrm{~min}$, dried at room temperature, and again blotted with filter paper to ensure tissue adherence.

The protocol for AVT immunocytochemistry was adapted from a procedure by Goodson and Bass (2000). Slides were immersed in PBS with $0.3 \%$ Triton X-100 (PBST) for $20 \mathrm{~min}$, followed by $0.025 \% \mathrm{H}_{2} \mathrm{O}_{2}$ for $15 \mathrm{~min}$ to eliminate endogenous peroxidases. Slides were then rinsed twice in PBS (10 min each), blocked with 10\% normal goat serum $(1 \mathrm{~h})$, and again rinsed with PBS (10 min). Anti-AVT antiserum (R-82 antiserum, kindly provided by Dr. F. van Leeuwen, Netherlands Institute for Brain Research, Amsterdam) was applied to slides at dilution of $1: 4000$ in PBST with $0.01 \%$ sodium azide for $16-18 \mathrm{~h}$ at $4{ }^{\circ} \mathrm{C}$. Secondary antibody binding was visualized by incubation with an avidin-biotin-peroxidase complex (rabbit IgG ABC Kit, Vector Laboratories) and diaminobenzidine (DAB, Sigma). Sections were then rinsed twice in $\mathrm{PB}$ (10 min each), rinsed in distilled $\mathrm{H}_{2} \mathrm{O}(5 \mathrm{~min})$, dehydrated in a graded ethanol series, and cleared in xylene before being coverslipped with Cytoseal 60 (Stephens Scientific). We preceded all postincubation rinses with a quick dip of the slides in PBS to reduce background staining.

The R-82 anti-AVT antiserum has been shown to label AVT in brain tissue from a variety of species including fish (e.g., Goodson and Bass, 2000; Moore et al., 2000). Moreover, preincubation of antiserum with AVT (10 and $100 \mu \mathrm{M}$ for $30 \mathrm{~h}$; Sigma) completely eliminated immunohistochemical staining, while preincubation with the related fish neuropeptide isotocin (10 and $100 \mathrm{M}$ for $30 \mathrm{~h}$; Sigma) did not block this staining. Sections run with exclusion of anti-AVT antiserum showed no DAB staining.

\subsection{Quantification of AVT immunoreactivity}

AVT-ir cell number and size were quantified using AxioVision software (Carl Zeiss, Oberkochen, Germany). Digitized images of tissue sections were captured by digital camera (Axiocam, Carl Zeiss) attached to a bright-field, light microscope (Axioskop, Carl Zeiss). Numbers of AVT-ir cell bodies were counted in serial sections beginning with the first visible AVT-ir cells in the nucleus preopticus parvocellularis anterioris $(\mathrm{PPa})$ and continuing through the nucleus preopticus magnocellularis until no more AVT-ir cells were visible.
For analysis, we grouped neurons from the PPa, nucleus preopticus parvocellularis posterioris $(\mathrm{PPp})$, and nucleus preopticus magnocellularis pars parvocellularis (PMp) as parvocellular neurons. AVT-ir neurons contained within the nucleus preopticus magnocellularis pars magnocellularis (PMm) and pars gigantocellularis $(\mathrm{PMg})$ were analyzed as magnocellular neurons. Neurons were classified by their size, morphology, and neuroanatomical location (see Braford and Northcutt, 1983; Peter et al., 1975), and our nomenclature of preoptic regions follows descriptions by Braford and Northcutt (1983).

We measured the size of AVT-ir cell soma as the cross-sectional area of an AVT-ir cell by tracing the cell soma's profile with a digitizing pen. Only cells displaying a distinct axon or dendrite were measured. Soma area $\left(\mu \mathrm{m}^{2}\right)$ or 'cell size' was automatically calculated by the AxioVision software, which had been calibrated with a micrometer. For each fish, we measured the size of $111.28 \pm 8.69$ (mean \pm SE; range, 45-200) parvocellular AVT-ir cells, and $45.86 \pm 3.75$ (range, 19-88) magnocellular cells. Values reported represent the mean soma size for each fish. Since tissue was sectioned at $30 \mu \mathrm{m}$ and immersed in anti-AVT antiserum while mounted on glass slides, it is unlikely that the same AVT-ir cell was counted in more than one section.

\subsection{Statistical analysis}

We used one-factor ANOVA's to test for differences in standard length and body weight among males and females from the Amargosa River and Big Spring populations. To determine whether either population or sex had an effect on mean AVT-ir cell number and size, we first used two-factor ANOVAs with population and sex as factors. Planned multiple comparisons both between sexes within a population and between same sex individuals among populations were then performed using Fisher's protected least-significant difference (LSD) tests. We also used linear regression to examine whether there was a relationship between body mass and both AVT-ir cell size and number. All statistical tests were two-sided.

\section{Results}

\subsection{Distribution of AVT immunoreactivity}

Fig. 1 presents schematic drawings of transverse sections that illustrate the distribution of AVT-ir cell bodies and fibers in the pupfish brain. No qualitative differences in the distribution of AVT-labeled neurons or fibers were apparent between either sexes or populations. Immunoreactive cell bodies and fibers were identified by a brown, $\mathrm{DAB}$ reaction precipitate against 

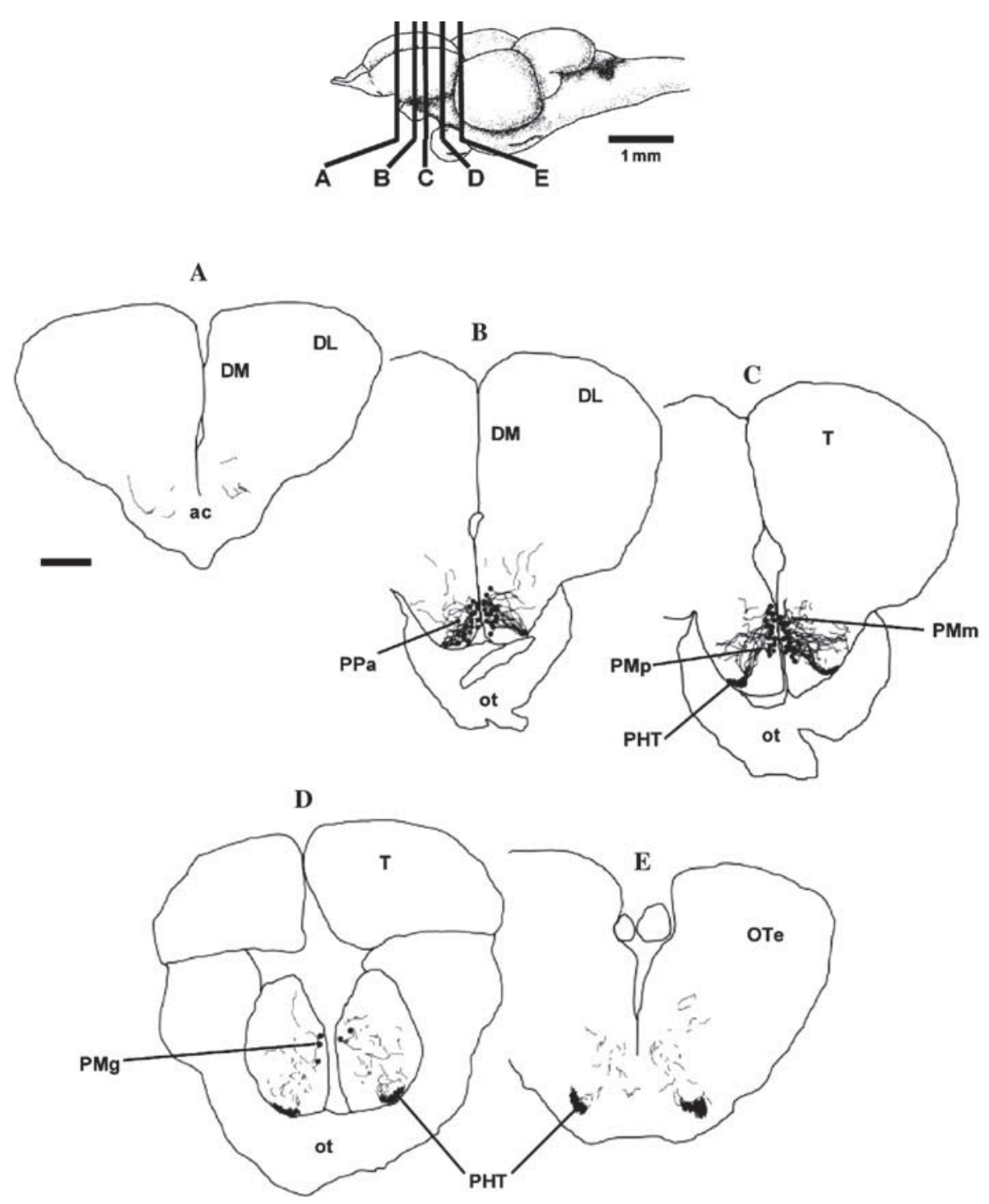

Fig. 1. (A-E) Line drawings of transverse sections showing the distribution of AVT-ir cells and fibers in the brain. Drawing of pupfish brain at top shows the approximate location of each section (A-E). AVT-ir cell bodies were restricted to the preoptic area with AVT-ir fibers extending to form the pituitary-hypophyseal tract (PHT). Abbreviations: ac, anterior commissure; DM, medial zone of dorsal telencephalon; DL, lateral zone of dorsal telencephalon; ot, optic tract; OTe, optic tectum; PMg, nucleus preopticus magnocellularis pars gigantocellularis; PMm, nucleus preopticus magnocellularis pars magnocellularis; PMp, nucleus preopticus magnocellularis pars parvocellularis; PPa, nucleus preopticus parvocellularis anterioris; $\mathrm{T}$, telencephalon. Scale bar $=200 \mu \mathrm{m}$ (shown in A).

minimal background staining. AVT-ir perikaya were restricted to the preoptic area of the hypothalamus. The most anteriorly located AVT-ir perikaya occurred in the $\mathrm{PPa}$, where AVT-ir labeled densely packed cells with small, round somata (Fig. 2A). Some AVT-ir fibers extended anteriorly from this region into the forebrain. Immunoreactive cell bodies were also located throughout the PMp and PMm (Fig. 2B), where large numbers of AVT-ir processes extended from the perikaya in the form of long, beaded fibers (Fig. 2C). Some of these fibers extended laterally and dorsally, but many contributed to the pituitary-hypophyseal tract (Fig. 2B). AVT-ir staining continued into the PMg (Figs. 2D, E), where the densely stained pituitary-hypophyseal tract was visible (Figs. 2D, F) and extended caudally to innervate the pituitary.

\subsection{Population differences in AVT-ir neuron size}

Fig. 3 shows the mean size $\left(\mu \mathrm{m}^{2}\right)$ and number of AVT-ir parvocellular neurons. We found that both population (two-factor ANOVA, $F_{1,17}=52.600$, $P<0.0001)$, and sex $\left(F_{1,17}=30.552, P<0.0001\right)$ had significant effects on variation in the size of parvocellular AVT-ir neurons. There was also a significant interaction between these two factors $\left(F_{1,17}=8.015, P=0.012\right)$. Pairwise comparisons between sexes showed that male Amargosa River pupfish had significantly larger 

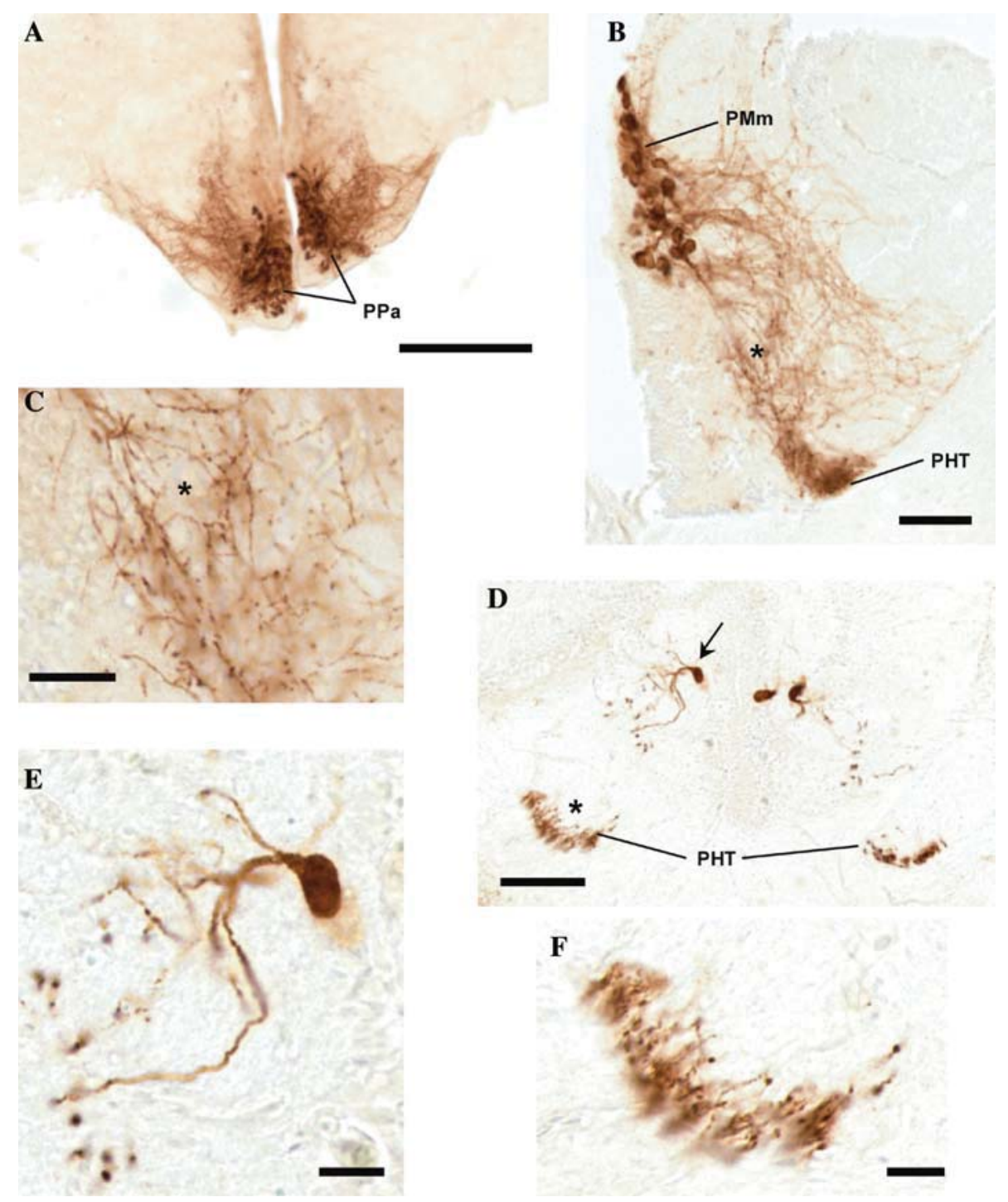

Fig. 2. (A-F) Representative images of AVT-ir staining in the preoptic area. (A) AVT-ir neurons within the nucleus preopticus parvocellularis anterioris (PPa). (B) AVT-ir cell and fiber staining in the magnocellular neurons (PMm) showing AVT-ir fibers innervating the pituitary-hypophyseal tract (PHT). (C) Higher power magnification of area of asterisk in (B) showing beaded AVT-ir fibers. (D) AVT-ir staining in the PHT and gigantocellular region of the nucleus preopticus magnocellularis. (E) Higher magnification view of AVT-ir neuron marked by arrow in (D). (F) Higher magnification view of PHT denoted by asterisk in D. Scale bars represent $200 \mu \mathrm{m}$ (A), $50 \mu \mathrm{m}$ (B), $20 \mu \mathrm{m}(\mathrm{C}, \mathrm{E}, \mathrm{F})$, and $100 \mu \mathrm{m}$ (D).

parvocellular neurons than females (Fisher's protected LSD, $P<0.0001$ ), while there was no difference between sexes in Big Spring fish $(P=0.079)$. When comparing between populations, Amargosa River males $(P<0.0001)$ and females $(P=0.007)$ both had larger parvocellular neurons than same sex fish from the Big Spring population. These population and sex differences in AVT-ir cell size cannot be attributed to body size since neither standard length $(\mathrm{mm})$ nor body weight $(\mathrm{g})$ differed among males and females in the populations (Table 2; one-factor ANOVA's: standard length, $F_{3,17}=0.5983, P=0.6248$; body wt, $F_{3,17}=0.5919$, $P=0.6288$ ). Furthermore, the size of these neurons showed no relationship to body weight in either the Amargosa River (linear regression, both sexes com- bined, $\left.r^{2}=0.036, P=0.577\right)$ or Big Spring $\left(r^{2}=0.004\right.$, $P=0.870)$ populations. In contrast, neither population (two-factor ANOVA, $F_{1,17}=0.962, P=0.341$ ) nor sex $\left(F_{1,17}=0.810, P=0.381\right)$ had an effect on the number of parvocellular AVT-ir neurons. While there was no significant relationship between the number of parvocellular AVT-ir cells and body weight in the Amargosa River population (linear regression, both sexes combined, $r^{2}=0.040, P=0.556$ ), we did find a positive relationship in Big Spring fish $\left(r^{2}=0.4667, P=0.029\right)$.

Among magnocellular neurons (Fig. 4), we also found significant variation in soma size between populations (two-factor ANOVA, $F_{1,17}=18.634, P=0.0005$ ) but not between sexes $\left(F_{1,17}=3.110, P=0.096\right)$, and the interaction between these two factors was not significant 

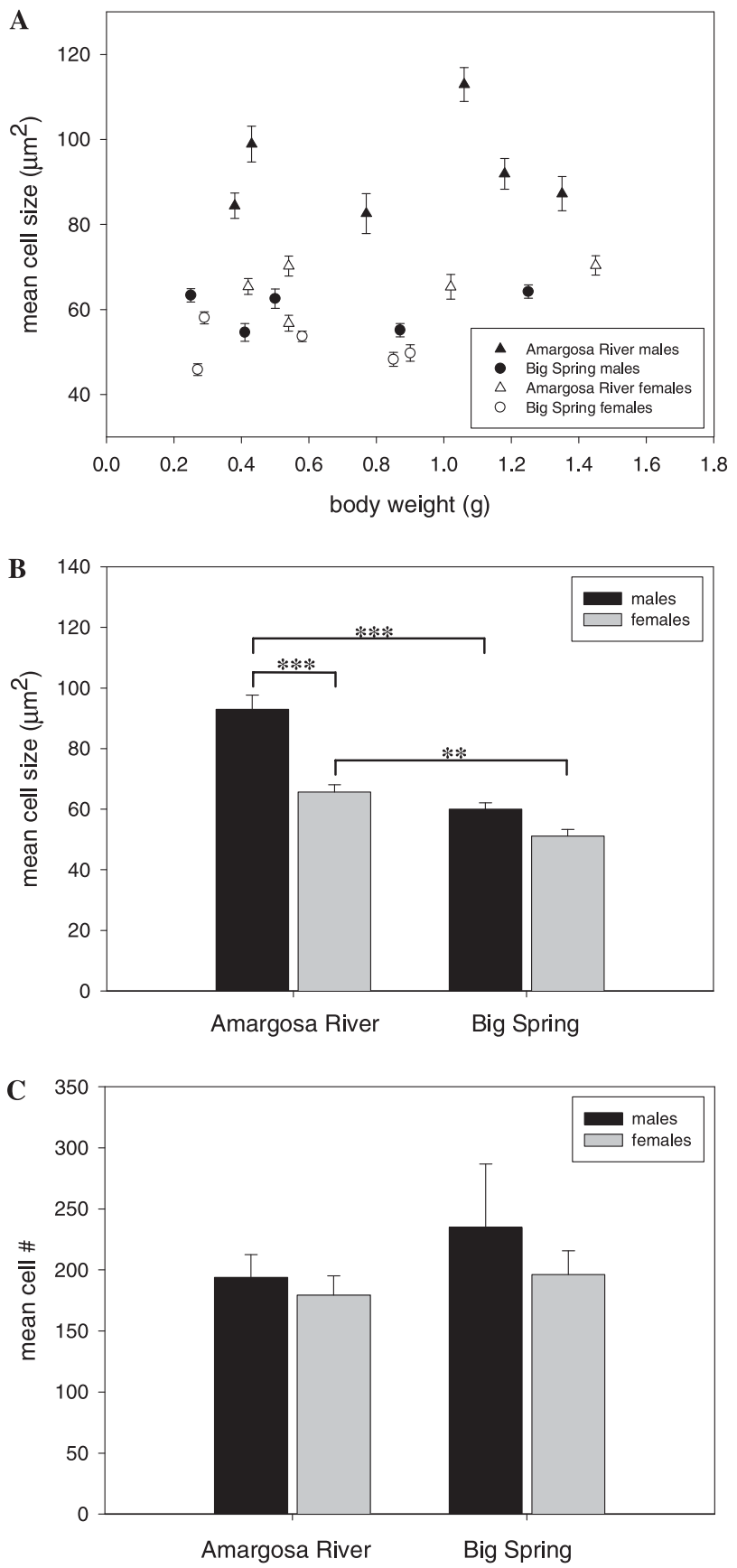

Fig. 3. (A) Mean soma size $\left(\mu \mathrm{m}^{2}\right)$ of parvocellular AVT-ir neurons plotted against body weight $(\mathrm{g})$ for individual males and females from the Amargosa River and Big Spring populations. Error bars indicate standard error of the mean for each fish. (B) Mean soma size of parvocellular neurons for males (black bars) and females (gray bars) from each population. Data are presented as mean \pm SE. Asterisks indicate significant differences between mean values (Fisher's protected LSD: ${ }^{* *} P<0.01 ;{ }^{* * *} P<0.0001$ ). (C) Mean number of parvocellular AVTir neurons for males (black bars) and females (gray bars) from each population.

$\left(F_{1,17}=0.695, \quad P=0.416\right) . \quad$ Pairwise comparisions showed that both Amargosa River males (Fisher's protected LSD, $P=0.002)$ and females $(P=0.027)$ had larger magnocellular AVT-ir neurons than same sex Big Spring pupfish. Quantification of soma area of these cells showed no relationship between magnocellular neuron size and body weight in the Amargosa River population (linear regression, both sexes combined, $\left.r^{2}=0.252, P=0.115\right)$, but a near significant relationship in Big Spring $\left(r^{2}=0.398, P=0.050\right)$. As with parvocellular neurons, we found no effect of either population $\quad\left(F_{1,17}=2.024, \quad P=0.173\right) \quad$ or $\quad$ sex $\left(F_{1,17}=0.405, \quad P=0.533\right)$ on magnocellular neuron number, and there was no significant relationship between the number of magnocellular AVT-ir cells and body weight in either Amargosa River $\left(r^{2}=0.004\right.$, $P=0.854)$ or Big Spring fish $\left(r^{2}=0.151, P=0.267\right)$.

\section{Discussion}

AVT-ir perikaya in the pupfish brain were limited to the preoptic area of the hypothalamus, with AVT-ir fibers extending to innervate the pituitary. This distribution of AVT-ir staining in Amargosa pupfish was similar to that previously recorded in other teleost fishes (e.g., Batten et al., 1990; Foran and Bass, 1998; Goodson and Bass, 2000; Schreibman and Halpern, 1980). The two populations examined in this study differed in the size of parvocellular and magnocellular AVT-ir neurons in the preoptic area. Males from the Amargosa River had parvocellular neurons that averaged $\sim 55 \%$ larger in soma area, and magnocellular neurons that were $\sim 60 \%$ larger than males from Big Spring. Females showed a similar trend-parvocellular AVT-ir neurons were $\sim 28 \%$ larger and magnocellular neurons $\sim 45 \%$ larger in Amargosa River females than in females from Big Spring. In other animal systems, changes in the size of hormone-containing neurons in the preoptic area have been linked to differences in systemic hormone levels (e.g., Francis et al., 1993). Whether larger AVT neurons in pupfish from the Amargosa River indicate increased secretion of the peptide or inhibition of secretion, however, cannot be concluded.

These differences in AVT-ir neuron size provide the first evidence that pupfish populations in Death Valley may have diverged in AVT physiology. What remains unclear, however, is whether these differences represent evolved changes in AVT neuroendocrinology, or whether they result from a plastic physiological response to dissimilar habitat conditions. Although we cannot currently distinguish between these alternatives, both scenerios suggest that ecological differences between habitats can affect AVT expression in the brain.

\subsection{Environmental differences between habitats}

Pupfish habitats in the Death Valley region are renowned for their ecological diversity, and the habitats 
Table 2

Comparison of mean $( \pm \mathrm{SE})$ standard length and body weight of $C$. nevadensis sampled from the Amargosa River and Big Spring populations

\begin{tabular}{lllll}
\hline Population & $N$ & Sex & Standard length $(\mathrm{mm})$ & Body weight $(\mathrm{g})$ \\
\hline Amargosa River & 6 & Male & $29.03 \pm 1.94$ & $0.86 \pm 0.16$ \\
& 5 & Female & $28.79 \pm 1.14$ & $0.79 \pm 0.18$ \\
Big Spring & 5 & Male & $26.29 \pm 2.48$ & $0.66 \pm 0.18$ \\
& 5 & Female & $26.20 \pm 2.13$ & $0.58 \pm 0.13$ \\
& & One-factor ANOVA & $F_{3,17}=0.5983$ & $F_{3,17}=0.5919$ \\
& & $P=0.6248$ & $P=0.6288$ \\
\hline
\end{tabular}

sampled in this study differ in variety of environmental parameters (see Table 1). The physical conditions in the Amargosa River are typical of a desert stream-the habitat fluctuates widely in temperature and experiences rapid changes in water flow as it floods following rain storms and desiccates in the extreme summer heat of Death Valley. This intermittent flooding and drying alters other parameters including the salinity and turbidity of the water. In contrast, Big Spring consists of a relatively stable springhead and outflow, receiving a continual influx of groundwater that maintains a constant temperature and salinity in the habitat.

These habitat differences have generated significant variation in the breeding behavior and demographics of the two populations. The Big Spring population is characterized as a territorial breeding system where males establish and defend reproductive territories over the substrate (Soltz, 1974). Males are highly aggressive, and females often initiate spawning. The size of the Big Spring population shows only minor variation over the course of a year, probably as a consequence of seasonal alterations in food availability. In contrast, Amargosa River pupfish generally breed in loose schools and aggregations, where males court females (see Soltz, 1974). Periodic flooding and seasonal changes in temperature cause 10 - to 20 -fold fluctuations in population size and density (Naiman, 1976; see Soltz and Naiman, 1978), which affect the reproductive behavior of fish in the river. The breeding system of Amargosa River pupfish thus oscillates between group spawning, where males do not defend territories but court females in schools, and a territorial breeding system.

\subsection{Ecological effects on brain AVT}

Given the degree of environmental differences between the Amargosa River and Big Spring, any number of parameters (i.e., salinity, temperature, social organization, etc.) might have generated differences in AVT neuron size. For instance, changes in salinity have been shown to alter levels of plasma AVT and magnocellular AVT mRNA in fish (Kulczykowska, 1997; Nürnberger et al., 1996). And in medaka (Oryzias latipes), transfer of freshwater acclimated fish to seawater decreased the number of magnocellular AVT-ir neurons, while simultaneously causing the nucleus size of these neurons to increase (Haruta et al., 1991).

AVT is also known to play a role in the stress response by stimulating release of ACTH from the pituitary (e.g., Baker et al., 1996). Recent evidence from rainbow trout (Oncorhynchus mykiss) has also shown that AVT mRNA is upregulated in parvocellular, but not magnocellular, neurons in response to acute stressors (Gilchriest et al., 2000). Although it is not clear how variation in the size of preoptic AVT-ir neurons relates to stress physiology, the differences that we found in the size of AVT neurons between Big Spring and Amargosa River pupfish could be associated with the need for these populations to cope with different environmental challenges.

Brain AVT/AVP has also been shown to underlie species differences in social behaviors in other animal systems (for review, see Insel and Young, 2000), and variation in preoptic AVT may be related to behavioral differences between pupfish populations as well. Provisional AVT receptors have been found in the dorsal telencephalon and preoptic area of fish (Moons et al., 1989), and the exogenous administration of AVT has been shown to alter social and reproductive behaviors in a number of species including pupfish (e.g., Lema and Nevitt, 2002; Salek et al., 2002). Variation in AVT neuron size may thus be associated with the differences in aggression and courtship seen between these populations (Soltz, 1974).

\subsection{Sexual dimorphisms and gonadal influences}

We also found that males from the Amargosa River had significantly larger AVT-ir parvocellular neurons compared to females from the same population. Whereas this was the only statistically significant sex difference in neuron size, larger sample sizes may have validated a trend toward larger parvocellular neurons in males from the Big Spring population as well. We specifically ran immunocytochemisty on pairs of same-sex Amargosa River and Big Spring pupfish to examine population differences in AVT expression, and comparisons between sexes may not be as robust as those between populations. Yet our finding of a sexual dimorphism is consistent with previous studies that have 

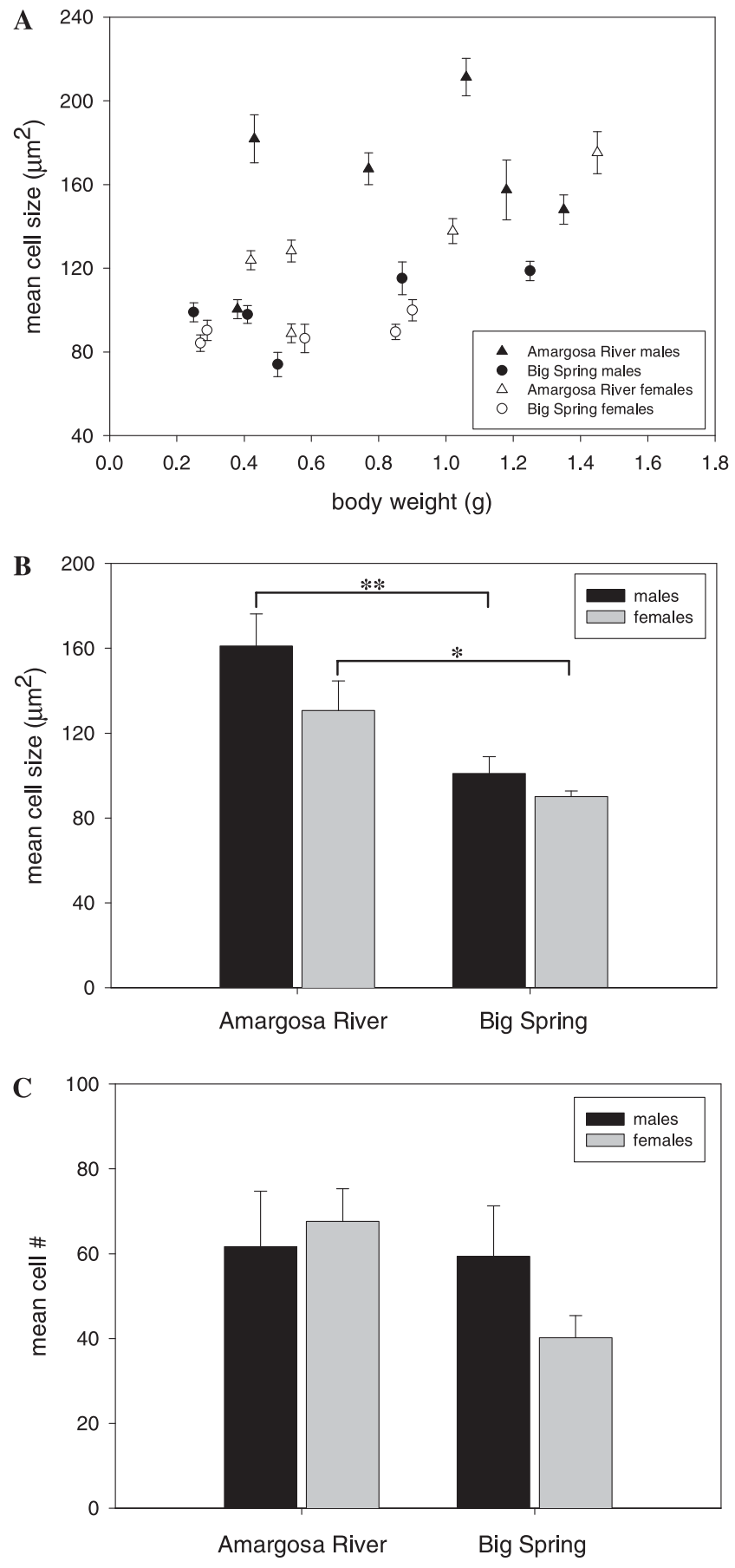

Fig. 4. (A) Mean soma size $\left(\mu \mathrm{m}^{2}\right)$ of magnocellular AVT-ir neurons plotted against body weight $(\mathrm{g})$ for males and females from the Amargosa River and Big Spring populations. Error bars indicate standard error of the mean for each fish. (B) Mean soma size of magnocellular neurons for males (black bars) and females (gray bars) from each population. Data are presented as mean \pm SE. Asterisks indicate significant differences between mean values (Fisher's protected LSD: $* P<0.05$; $* *<0.01$ ). (C) Mean number of magnocellular AVT-ir neurons for males (black bars) and females (gray bars) from each population.

shown AVT dimorphisms in brain areas homologous to the parvocellular-and not the magnocellular-nucleus of teleost fishes (for review, see Goodson and Bass,
2001). Such studies have generally shown that males display more brain AVT-ir staining than females and that these dimorphisms can mediate behavioral differences between the sexes.

A variety of evidence indicates that the differences in AVT neuron size that we found were not caused by variation in size at sexual maturation. Soltz (1974) compared gonadal state in wild-caught pupfish from the same habitats sampled here and found that males from both populations matured at the same size ( $20 \mathrm{~mm}$ standard length) while Amargosa River females matured at a larger size ( $24 \mathrm{~mm}$ ) than their Big Spring counterparts $(20 \mathrm{~mm})$. All but perhaps the smallest pupfish sampled in the current study can thus be considered sexually mature. Moreover, we intentionally sampled pupfish at a time of year when both populations were breeding and males displayed coloration typical of being reproductively active. The differences in AVT neuron size between these populations thus do not appear to be caused by variation in gonadal state. Recent work by Semsar and Godwin (2003) in the bluehead wrasse (Thalassoma bifasciatum) supports this idea, as they found that gonadal state influenced the soma size of gigantocellular AVT-ir neurons, and did not affect the size of parvocellular or magnocellular neurons.

\section{Conclusion}

While many studies have compared the neuroendocrinology of distinct species, surprisingly little work has been conducted at the level of populations. We thus understand little about the role that neuroendocrine changes play in the initial stages of evolutionary divergence. Here, we have shown that two recently isolated populations of Death Valley pupfish differ in the size of preoptic AVT neurons. At present we do not know what caused these differences. It is clear from studies in other taxa that the soma size of preoptic neurons can be condition-sensitive (e.g., Francis et al., 1993), and the population differences that we observed could result from a plastic response to variation in salinity, temperature, or social circumstances between habitats. Further work is needed, for example, to examine whether these population differences in AVT neuron size are maintained when fish develop under similar environmental conditions. And because of the protected conservation status of pupfishes in the Death Valley region, we only sampled populations in the Spring. Sampling over multiple seasons and examining additional Death Valley populations could help us understand which factors are responsible for population variation in brain AVT.

Still, it is interesting to consider what significance differences in preoptic AVT might hold for the evolution of Death Valley pupfishes. Even if this population var- 
iation was caused by a condition-sensitive regulation of AVT expression, such changes might lead to a cascade of effects on physiological and behavioral traits important to survival and reproduction. An initial, plastic change in neuroendocrinology might thus start populations on different evolutionary trajectories. Determining what causes the differences in AVT neurons size and what significance they hold for the evolution of Death Valley pupfishes could greatly contribute to our understanding of how brain and behavior evolve.

\section{Acknowledgments}

This research was primarily supported by an NSF Graduate Research Fellowship and UC Davis Jastro Shields Scholarship to S.C.L. Additional support was provided by NIH (PHS DCO3174 to G.A.N.). Thanks to Eric Hopson and David St. George for assistance with fish collection, and Tom Hahn for providing a cryostat. Pupfish were collected under permission of the US Fish and Wildlife Service (TE031898-0), US Bureau of Land Management (CA-680.32), Ash Meadows National Wildlife Refuge (14554-00004), Nevada Division of Wildlife (S 21526), and California Department of Fish and Game (803065-04). All research was carried out following guidelines of the Animal Care and Use Committee of the University of California, Davis. The authors thank R. Kihslinger, P. Swanson, and two anonymous reviewers whose comments greatly improved the quality of this paper.

\section{References}

Baker, B.I., Bird, D.J., Buckingham, J.C., 1996. In the trout, CRH and AVT synergize to stimulate ACTH release. Regul. Pept. 67, 207210.

Batten, T.F.C., Cambre, M.L., Moons, L., Vandesande, F., 1990. Comparative distribution of neuropeptide-immunoreactive systems in the brain of the green molly, Poecilia latipinna. J. Comp. Neurol. 302, 893-919.

Bester-Meredith, J.K., Young, L.J., Marler, C.A., 1999. Species differences in paternal behavior and aggression in Peromyscus and their associations with vasopressin immunoreactivity and receptors. Horm. Behav. 36, 25-38.

Braford Jr., M.R., Northcutt, R.G., 1983. Organization of the diencephalons and pretectum of the ray-finned fishes. In: Northcutt, R.G., Davis, R.E. (Eds.), Fish Neurobiology, vol. 2. Univ. of Michigan Press, Ann Arbor, pp. 117-163.

Cushing, B.S., Martin, J.O., Young, L.J., Carter, C.S., 2001. The effects of peptides on partner preference formation are predicted by habitat in prairie voles. Horm. Behav. 39, 48-58.

Duvernell, D.D., Turner, B.T., 1998. Evolutionary genetics of Death Valley pupfish populations: mitochondrial DNA sequence variation and population structure. Mol. Ecol. 7, 279-288.

Enzel, Y., Wells, S.G., 1997. Extracting holocene paleohydrology and paleoclimatology information from modern extreme flood events: an example from southern California. Geomorphology 19, 203226.
Foran, C.M., Bass, A.H., 1998. Preoptic AVT immunoreactive neurons of a teleost fish with alternative reproductive tactics. Gen. Comp. Endocrinol. 111, 271-282.

Francis, R.C., Soma, K., Fernald, R.D., 1993. Social regulation of the brain-pituitary-gonadal axis. Proc. Natl. Acad. Sci. USA 90, 7794-7798.

Gilchriest, B.J., Tipping, D.R., Hake, L., Levy, A., Baker, B.I., 2000. The effects of acute and chronic stresses on vasotocin gene transcripts in the brain of the rainbow trout (Oncorhynchus mykiss). J. Neuroendocrinol. 12, 795-801.

Goodson, J.L., Bass, A.H., 2000. Vasotocin innervation and modulation of vocal-acoustic circuitry in the teleost Porichthys notatus. J. Comp. Neurol. 422, 363-379.

Goodson, J.L., Bass, A.H., 2001. Social behavior functions and related anatomical characteristics of vasotocin/vasopressin systems in vertebrates. Brain Res. Rev. 35, 246-265.

Haruta, K., Yamashita, T., Kawashima, S., 1991. Changes in arginine vasotocin content of the pituitary of the medaka (Oryzias latipes) during osmotic stress. Gen. Comp. Endocrinol. 83, 327336.

Hirshfield, M.F., Feldmeth, C.R., Soltz, D.L., 1980. Genetic differences in physiological tolerance of Amargosa pupfish (Cyprinodon nevadensis) populations. Science 207, 999-1001.

Insel, T.R., Young, L.J., 2000. Neuropeptides and the evolution of social behavior. Curr. Opin. Neurobiol. 10, 784-789.

Ketterson, E.D., Nolan Jr., V., 1999. Adaptation, exaptation, and constraint: a hormonal perspective. Am. Nat. 154, S4-S25.

Kulczykowska, E., 1997. Response of circulating arginine vasotocin and isotocin to rapid osmotic challenge in rainbow trout. Comp. Biochem. Physiol. A 118, 773-778.

Lema, S.C., Nevitt, G.A., 2002. Arginine vasotocin modulates social behaviors in a Death Valley pupfish. Integr. Comp. Biol. 42, 1265.

Lema, S.C., Nevitt, G.A., 2003. Evidence of a neuroendocrine basis for rapid evolution in Death Valley pupfishes. Program No. 943. 4. 2003 Abstract/Itinerary Planner. Society for Neuroscience, Washington, DC.

Miller, R.R., 1981. Coevolution of deserts and pupfishes (genus: Cyprinodon) in the American Southwest. In: Naiman, R.J., Soltz, D.L. (Eds.), Fishes in North American Deserts. Wiley, New York, pp. 39-94.

Miller, R.R., 1948. The cyprinodont fishes of the Death Valley system of eastern California and southwestern Nevada. Miscell. Pub. Mus. Zool., Univ. of Michigan 68, 1-155.

Moons, L., Cambré, M., Batten, T.F.C., Vandesande, F., 1989. Autoradiographic localization of binding sites for vasotocin in the brain and pituitary of the sea bass (Dicentrarchus labrax). Neurosci. Lett. 100, 11-16.

Moore, F.L., Richardson, C., Lowry, C.A., 2000. Sexual dimorphism in numbers of vasotocin-immunoreactive neurons in brain areas associated with reproductive behaviors in the roughskin newt. Gen. Comp. Endocrinol. 117, 281-298.

Naiman, R.J., 1976. Productivity of a herbivorous pupfish population (Cyprinodon nevadensis) in a warm desert stream. J. Fish Biol. 9, $125-137$.

Nürnberger, F., Korf, H-W., Ather Ali, M., Noakes, D.L.G., 1996. Salinity and vasotocin immunoreactivity in the brain of Rivulus marmoratus (teleostei). Naturwissenschaften 83, 326-328.

Peter, R.E., Macey, M.J., Gill, V.E., 1975. A stereotaxic atlas and technique for forebrain nuclei of the killifish, Fundulus heteroclitus. J. Comp. Neurol. 159, 103-128.

Rose, J.D., Kinnaird, J.R., Moore, F.L., 1995. Neurophysiological effects of vasotocin and corticosterone on medullary neurons: implications for hormonal control of amphibian courtship behavior. Neuroendocrinology 62, 406-417.

Salek, S.J., Sullivan, C.V., Godwin, J., 2002. Arginine vasotocin effects on courtship behavior in male white perch (Morone americana). Behav. Brain Res. 133, 177-183. 
Schreibman, M.P., Halpern, L.R., 1980. The demonstration of neurophysin and arginine vasotocin by immunocytochemical methods in the brain and pituitary gland of the platyfish, Xiphophorus maculates. Gen. Comp. Endocrinol. 40, 1-7.

Semsar, K., Godwin, J., 2003. Social influences on the arginine vasotocin system are independent of gonads in a sex-changing fish. J. Neurosci. 23, 4386-4393.

Soltz, D.L., 1974. Variation in life history and social organization of some populations of Nevada pupfish, Cyprinodon nevadensis. Ph.D. thesis, Univ. of California, Los Angeles.

Soltz, D.L., Hirshfield, M.F., 1981. Genetic differentiation of pupfishes (genus Cyprinodon) in the American southwest. In: Naiman, R.J.,
Soltz, D.L. (Eds.), Fishes in North American Deserts. Wiley, New York, pp. 291-333.

Soltz, D.L., Naiman, R.A., 1978. The natural history of native fishes in the Death Valley system. Nat. Hist. Mus. Los Angeles County, Sci. Ser. 30, 1-76.

Warne, J.M., Balment, R.J., 1997. Vascular variations of neurohypophysial peptides in the flounder. Fish Physiol. Biochem. 17, 313318

West-Eberhard, M.J., 1992. Behavior and evolution. In: Grant, P.R., Horn, H.S. (Eds.), Molds, Molecules, and Metazoa: Growing Points in Evolutionary Biology. Princeton University Press, Princeton, NJ, pp. 57-75. 